\title{
26. LATE CRETACEOUS PLANKTONIC FORAMINIFERA FROM THE NORTHWESTERN PACIFIC: LEG 32 OF THE DEEP SEA DRILLING PROJECT
}

\author{
Michèle Caron, Institute of Geology, University of Fribourg, Switzerland
}

\section{INTRODUCTION}

During Leg 32 of the Deep Sea Drilling Project, Late Cretaceous deposits were sampled at three sites: Site 305 (Shatsky Rise), Site 310 (Hess Rise), and Site 313 (northeastern Mid-Pacific Mountains). The CretaceousTertiary boundary was not recovered at these sites because it is probably marked by a hiatus (Site 305: base of Core 14-middle Paleocene, top of Core 15-late Maestrichtian; Site 310: base of Core 11-middle to early Eocene, top of Core 12-early Campanian; Site 313: Core 14-early Eocene, top of Core 15-middle Maestrichtian).

The complete late Senonian (Maestrichtian and Campanian) is represented only on Shatsky Rise (Site 305). On Hess Rise (Site 310), the youngest microfaunas of the Upper Cretaceous are attributed to the early Campanian. At Site 313, the uppermost zone of the Maestrichtian is lacking, and the early Campanian microfaunas are sparse in Cores 40 to 42 .

The early Senonian (Santonian and Coniacian) is well developed in Hole 310A (Hess Rise), although much of this section is heavily contaminated by Cenozoic microfaunas because of the drilling. On Shatsky Rise recovery of the early Senonian interval was very low, and the microfaunas are therefore poorly represented.

Turonian to Cenomanian microfaunas were only recovered in Hole $310 \mathrm{~A}$, but at this site also, poor recovery precludes a detailed study of this interval.

In general, the preservation of Late Cretaceous planktonic foraminifera is good, especially in the Campanian and lower Maestrichtian of Shatsky Rise and in parts of the lower Campanian of Hess Rise. Late Maestrichtian microfaunas were found only at Site 305 , but the upper part of this interval is strongly affected by dissolution. The Santonian microfaunas are generally well preserved, whereas the degree of dissolution in the Coniacian, Turonian, and Cenomanian varies widely.

For details on the specific composition and other characteristics of the studied samples, reference is made to the corresponding distribution ${ }^{-}$charts (Figures 1, 2, and 3) which represent the main document of this chapter.

\section{SITE 305-SHATSKY RISE}

(lat $32^{\circ} 00.13^{\prime} \mathrm{N}$, long $157^{\circ} 51.00^{\prime} \mathrm{E}$, water depth $2903 \mathrm{~m}$ )

Core 15 , which is attributed to the Late Maestrichtian Globotruncana mayaroensis Zone, has a very impoverished microfauna with a high percentage of benthonic foraminifera. The effects of dissolution on the planktonic foraminifera are strong to very strong.
The microfaunas of the main part of the Late Cretaceous (Cores 16 to 35 ) are generally very well preserved, except within the late Campanian Globotruncana calcarata Zone, where the frequency of the microfaunas becomes very irregular. A few intervals are strongly affected by dissolution resulting in a drastic decrease of the percentage of planktonic foraminifera in the total foraminiferal fauna (e.g., Core 21, Section 5).

In the samples displaying strong dissolution effects, globotruncanids with one or two keels dominate. This confirms the observation by Douglas (1971) that globotruncanids are the most dissolution-resistant forms among the Late Cretaceous planktonic foraminifera. However, well-preserved specimens of $\mathrm{Hed}$ bergella holmdelensis are found together with "skeletons" of keeled globotruncanids in samples with strong dissolution effects, from both Shatsky Rise and Hess Rise. The representatives of this species do not follow the usual succession of selective dissolution (Douglas, 1971, p. 1041) which might be explained by a differing chemical composition or morphology of their test (thicker wall, smaller and less densely spaced pores).

A second interval with strong dissolution may occur between Core 35, attributed to the Coniacian, and Core 37 of early Cenomanian age. However, the recovery of Core 36 consists only of a few chert pieces and it is therefore not possible to determine whether deposits of Turonian to middle Cenomanian age are greatly reduced in thickness or completely absent.

\section{SITE 310-HESS RISE}

(lat $36^{\circ} 52.11^{\prime} \mathrm{N}$, long $176^{\circ} 54.09^{\prime} \mathrm{E}$, water depth $3516 \mathrm{~m}$ )

All stages from the Campanian to the Cenomanian are represented in the section recovered on Hess Rise, but study of these microfaunas is hampered by intensive downhole contaminations by Cenozoic microfaunas (especially Site 310 , Cores 12 to 21 ; Site 310 A, Cores 1 , 2 , and 13).

In place Maestrichtian strata were not recovered on Hess Rise, but occasional caved specimens from this stage (e.g., Globotruncana stuarti, G. contusa) were found down to the base of Core 4A. The difficulties caused by the presence of these younger contaminants are enhanced by the more or less advanced dissolution of the autochthonous planktonic foraminifera.

The microfaunas of the remaining part of the section (early Senonian, Turonian, Cenomanian) are better preserved. The main biozones Globotruncana concavata Zone (Santonian), Globotruncana primitiva Zone (Coniacian), Praeglobotruncana helvetica Zone (Turonian), and Rotalipora apenninica Zone (Cenomanian) can be recognized without difficulty. 


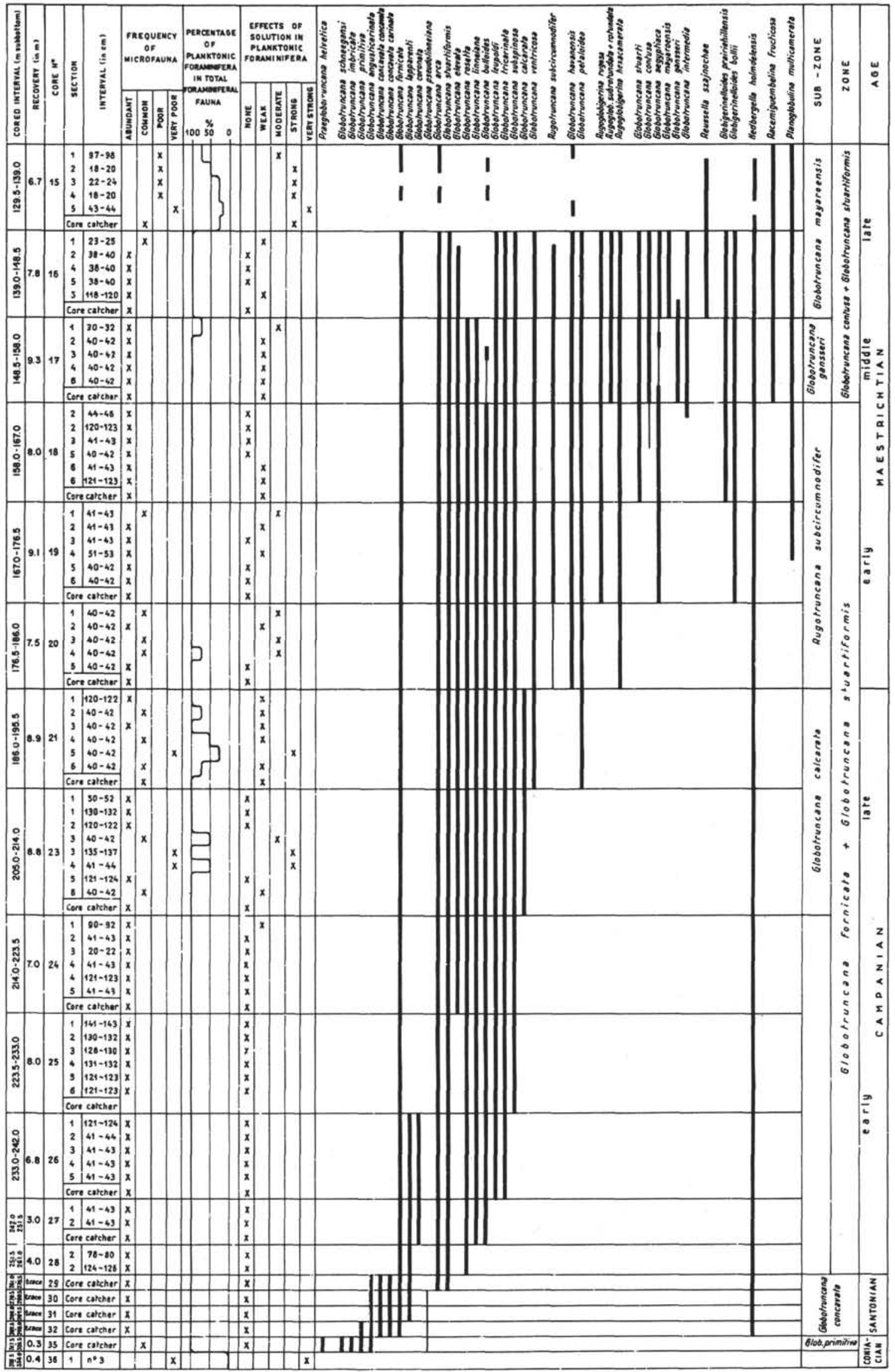

Figure 1. Distribution of planktonic foraminifera in Cores 15 to 36, Site 305. 


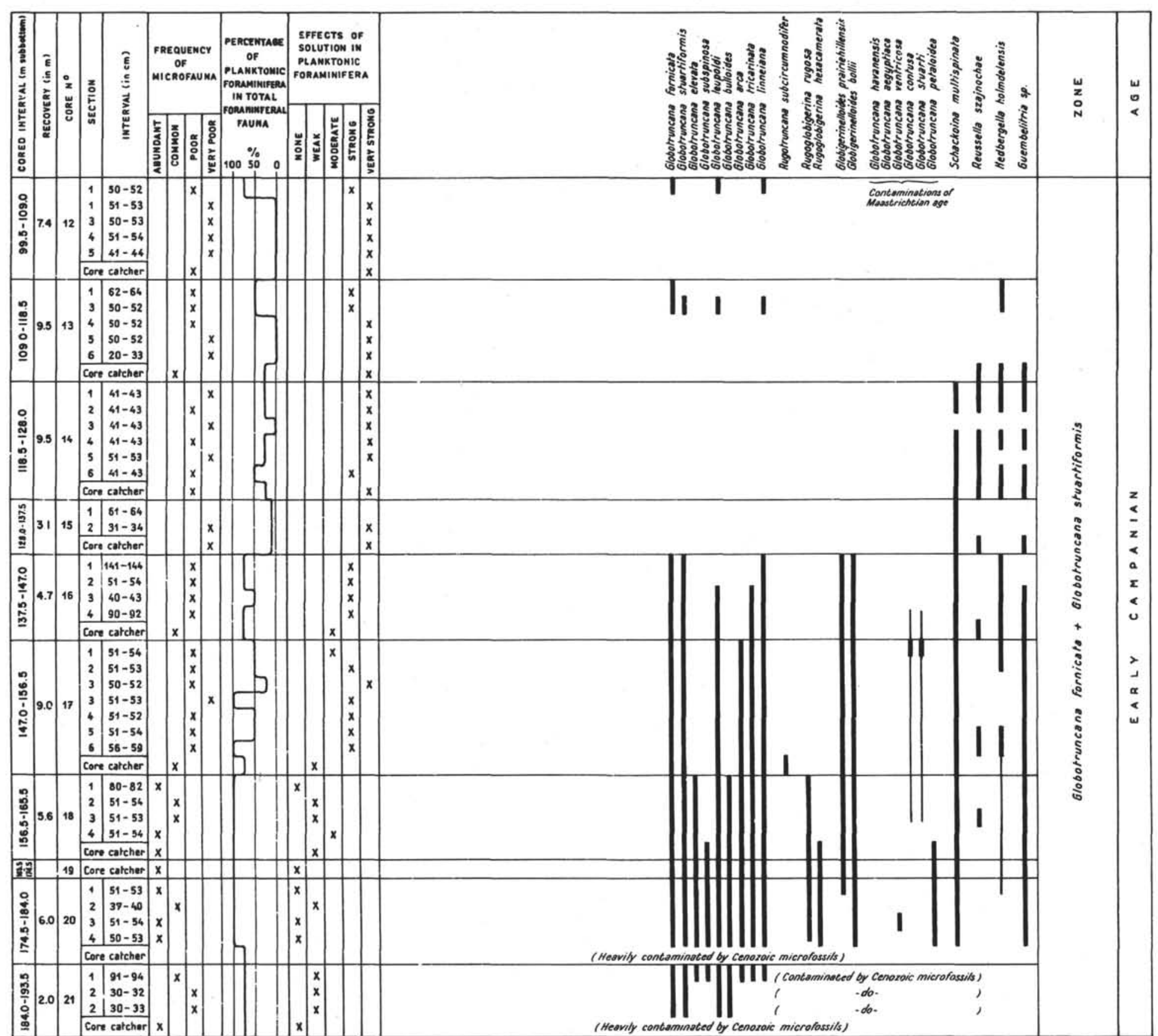

Figure 2. Distribution of planktonic foraminifera/in Cores 12 to 21, Site 310. 


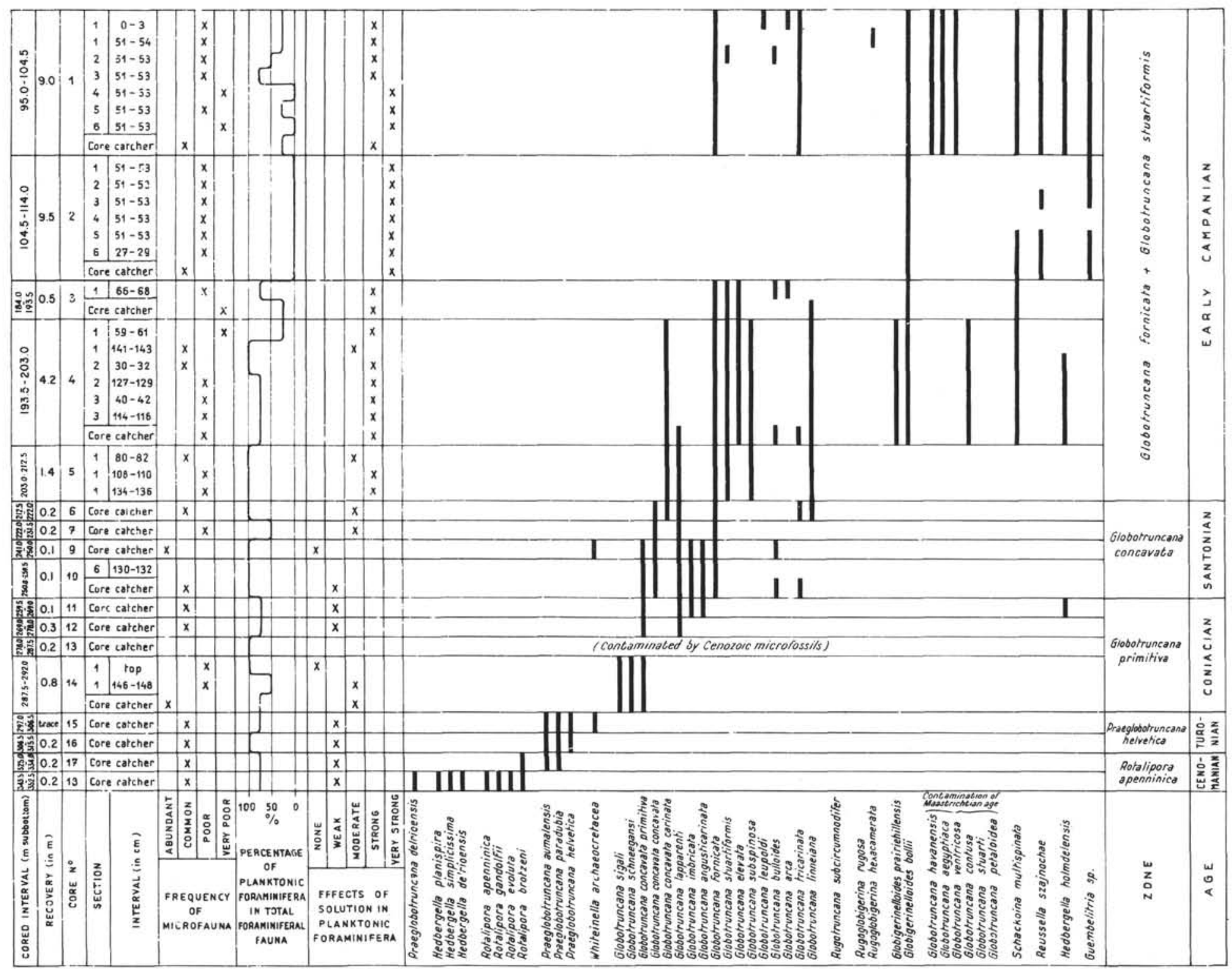

Figure 2. (Continued). Distribution of planktonic foraminifera in Cores 1 to 18, Site $310 \mathrm{~A}$. 


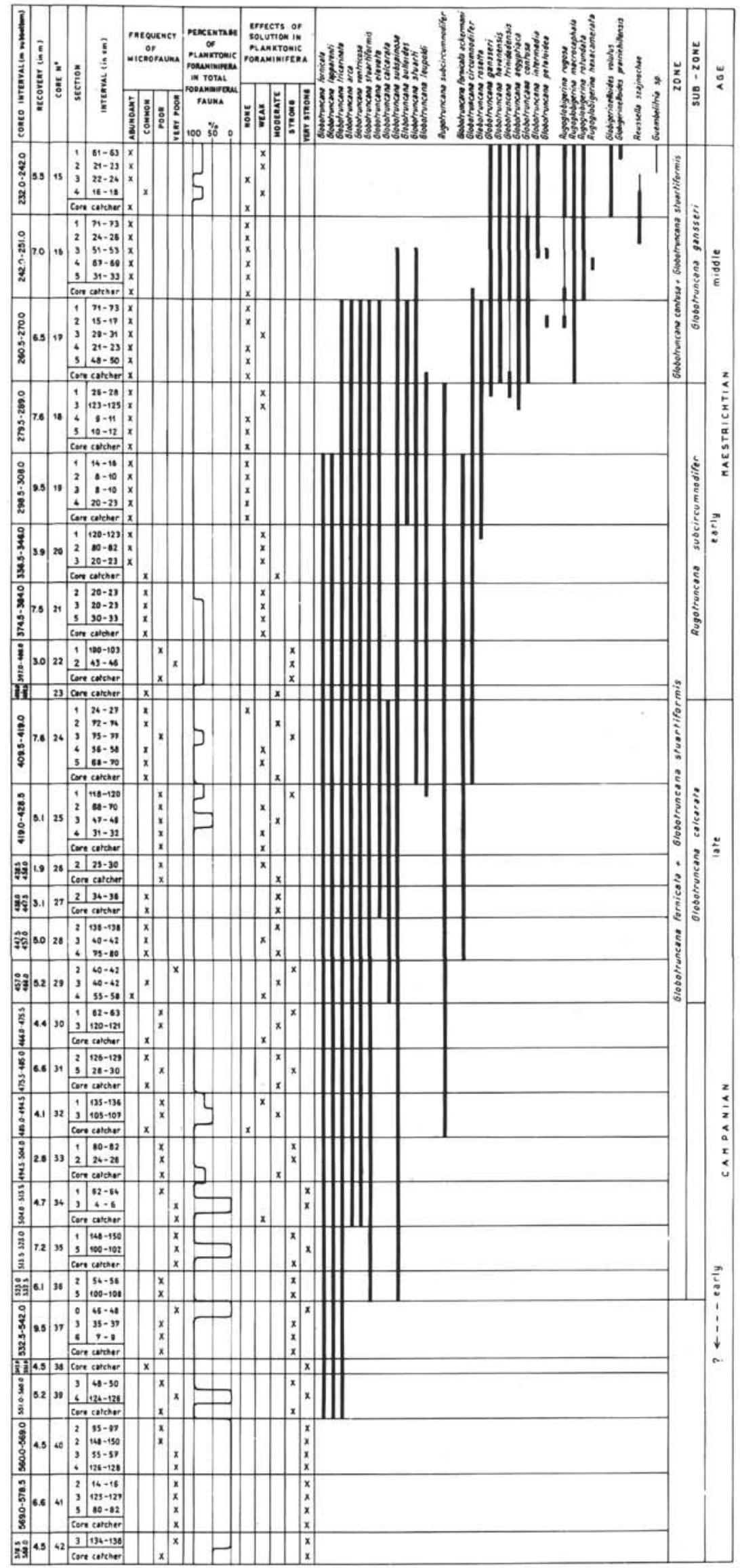

Figure 3. Distribution of planktonic foraminifera in Cores 15 to 42, Site 313. 


\section{SITE 313-NORTHEASTERN \\ MID-PACIFIC MOUNTAINS \\ (lat $20^{\circ} 10.52^{\prime} \mathrm{N}$, long $170^{\circ} 57.15^{\prime} \mathrm{W}$, water depth $3484 \mathrm{~m}$ )}

The nature of the Cretaceous-Tertiary boundary cannot be specified because Core 14 consists only of a few chert chips attributed to the early Eocene and only 58\% of Core 15 was recovered. The top of Core 15 belongs to the middle Maestrichtian Globotruncana gansseri Subzone, characterized by the coexistence of Globotruncana gansseri, G. contusa, and G. stuartiformis.

The excellent preservation and high abundance of Maestrichtian planktonic foraminifera indicate favorable and stable conditions during most of that time. Starting in Campanian time, turbidite deposition, resulting from submarine volcanism, strongly influences the frequency and preservation of the planktonic foraminifera. The degree of dissolution of foraminiferal tests is very variable. From Core 34 downwards, the number of planktonic foraminifera strongly declines, and their preservation deteriorates. In the lowermost three cores above the basalt (Cores 40, 41, 42), planktonic foraminifera are completely destroyed by dissolution. The lowermost age-significant planktonic foraminiferal faunas are found in Core 36 and are attributed to the early Campanian.

\section{REFERENCE}

Douglas, R., 1971. Cretaceous Foraminifera from the Northwestern Pacific Ocean: Leg 6, Deep Sea Drilling Project. Initial Rep. of the DSDP, vol. VI, p. 1027-1053. 